\title{
Pengaruh Makro Ekonomi, Struktur Modal, Struktur Kepemilikan, Faktor Teknikal terhadap Profitabilitas dengan Total Pendapatan Sebagai Variabel Intervening pada Sub Sektor Perkebunan Di Bursa Efek Indonesia Periode 2014-2020
}

\author{
Yunan Surono*, Muhammad Ade Masyhuri \\ Fakultas Ekonomi Univesitas Batanghari \\ *Correspondence email: suronoyunan@gmail.com, muhammadade55.ma@gmail.com
}

\begin{abstract}
Abstrak. Penelitian ini bertujuan untuk melihat hubungan antara variabel makro ekonomi, struktur modal, struktur kepemilikan, faktor teknikal terhadap variabel profitabilitas dengan total pendapatan sebagai variabel intervening pada kelompok saham sub sektor perkebunan di Bursa Efek Indonesia periode 2014 - 2020. Penelitian ini menggunakan analisis SEM (Structural Equation Modeling) berbasis component atau variance yakni Partial Least Square (PLS), dengan menggunakan software Smart PLS 3.0. Hasil penelitian menunjukkan 1) variabel makro ekonomi tidak berpengaruh terhadap total pendapatan. 2) variabel struktur modal tidak berpengaruh terhadap total pendapatan. 3) variabel struktur kepemilikan berpengaruh terhadap total pendapatan. 4) variabel faktor teknikal tidak berpengaruh terhadap total pendapatan. 5) variabel makro ekonomi berpengaruh terhadap profitabilitas. 6) variabel struktur modal tidak berpengaruh terhadap profitabilitas. 7) variabel struktur kepemilikan tidak berpengaruh terhadap profitabilitas. 8) variabel faktor teknikal berpengaruh terhadap profitabilitas. 9) Makro ekonomi tidak berpengaruh terhadap profitabilitas melalui total pendapatan. 10) struktur modal tidak berpengaruh terhadap profitabilitas melalui total pendapatan. 11) struktur kepemilikan tidak berpengaruh terhadap profitabilitas melalui total pendapatan. 12). faktor teknikal tidak berpengaruh terhadap profitabilitas melalui total pendapatan.
\end{abstract}

Kata kunci: makro ekonomi; struktur modal; struktur kepemilikan; factor teknikal; profitabilitas; intervening

\begin{abstract}
This study aims to see the relationship between macroeconomic variables, capital structure, ownership structure, technical factors on profitability variables with total income as an intervening variable in the plantation sub-sector stock group on the Indonesia Stock Exchange for the period 2014 - 2020. This study uses SEM (Structural) analysis. Equation Modeling) based on component or variance, namely Partial Least Square (PLS), using Smart PLS 3.0 software. The results showed that 1) macroeconomic variables had no effect on total income. 2) capital structure variable has no effect on total income. 3) ownership structure variable has an effect on total income. 4) technical factor variables have no effect on total income. 5) macroeconomic variables affect profitability. 6) the capital structure variable has no effect on profitability. 7) ownership structure variable has no effect on profitability. 8) technical factor variables affect profitability. 9) Macro economy has no effect on profitability through total income. 10) capital structure has no effect on profitability through total income. 11) ownership structure has no effect on profitability through total income. 12). technical factors have no effect on profitability through total revenue.
\end{abstract}

Keywords: macro economy; capital structure; ownership structure; technical factors; profitability; intervening.

\section{PENDAHULUAN}

Investor dalam berinvestasi akan melakukan analisis fundamental secara "top-down" guna menilai prospek suatu perusahaan. Pertama kali yang perlu dilakukan adalah analisa terhadap faktor-faktor makro ekonomi yang mempengaruhi kinerja seluruh perusahaan, kemudian analisis terhadap industri dan terakhir pada analisis terhadap perusahaan yang mengeluarkan sekuritas yang bersangkutan untuk menilai apakah sekuritas yang dikeluarkannya menguntungkan atau merugikan bagi investor. (Tandelilin, 2010). Penelitian ini menggunakan variabel bebas yakni makro ekonomi, struktur modal, struktur kepemilikan, faktor teknikal, juga menggunakan variabel profitabilitas sebagai variabel terikat serta variabel total pendapatan sebagai variabel intervening.

Analisis dimulai dengan menggunakan variabel makro ekonomi yang terdiri dari tingkat inflasi, tingkat suku bunga bank sentral, kurs mata uang rupiah terhadap US dollar dan jumlah uang beredar (JUB). Inflasi merupakan kecenderungan kenaikan harga-harga umum secara terus menerus, semakin tinggi inflasi akan semakin tinggi harga-harga umum di pasar. Indikator lain yang digunakan dalam penelitian ini yakni kurs US dollar, yaitu nilai mata uang US dollar dibandingkan dengan mata uang rupiah. Jika kurs mata uang asing semakin tinggi dibanding rupiah, maka investor cenderung akan menanamkan uangnya ke valuta asing, karena untuk berspekulasi dan menjaga semakin menurunnya nilai rupiah (depresiasi). Selain menggunakan data inflasi dan kurs US dollar, juga menggunakan indikator tingkat suku bunga BI- 7 days repo rate. Jika suku bunga bank tinggi, maka investor banyak yang menanamkan dananya pada bank, dan kesempatan menanamkan dananya ke pasar modal akan berkurang. Selain variabel makro ekonomi, kinerja 
Yunan Surono dan Muhammad Ade Masyhuri, Pengaruh Makro Ekonomi, Struktur Modal, Struktur Kepemilikan, Faktor Teknikal terhadap Profitabilitas dengan Total Pendapatan Sebagai Variabel Intervening pada Sub Sektor Perkebunan Di Bursa Efek Indonesia Periode 2014-2020

keuangan suatu perusahaan tergambar dari laporan keuangannya, yang terdiri dari neraca, laporan rugi laba, laporan perubahan modal, laporan arus kas dan catatan atas laporan keuangan. Salah satu cara yang digunakan adalah analisis rasio keuangan antara lain rasio likuiditas, aktivitas, profitabilitas, solvabilitas dan nilai pasar (Kasmir, 2014).

Struktur modal merupakan perimbangan jumlah hutang jangka pendek yang bersifat tetap, hutang jangka panjang, saham preferen, dan saham biasa (Halim, 2000). Struktur modal yang mengalami perubahan setiap tahunnya dari masing masing perusahaan emiten, apakah berpengaruh atau tidak terhadap profitabilitas. Jika ada pengaruhnya, berarti struktur modal mempunyai pengaruh yang baik dalam perusahaan, tetapi jika tidak ada pengaruhnya, berarti struktur modal mempunyai pengaruh yang tidak baik dalam perusahaan. Pemenuhan modal yang bersumber dari dana eksternal akan menentukan kemampuan perusahaan dalam melakukan aktivitasnya sekaligus meningkatkan risiko keuangan perusahaan tersebut. Penelitian ini menggunakan variabel struktur modal (solvabilitas) yakni berupa Debt to Asset Ratio (DAR) dan Debt to Equity Ratio (DER). Proporsi kepemilikan perusahaan juga menjadi variabel penting dalam mengelola dan menentukan arah kebijakan manajemen dimasa yang akan datang, sebab jumlah porsi kepemilikan perusahaan akan memberikan hak mutlak dalam menentukan arah manajemen dalam menjalankan semua kegiatan dan operasi perusahaan.

Variabel struktur kepemilikan juga digunakan dalam penelitian ini, struktur kepemilikan merupakan proporsi kepemilikan institusional dan manajemen dalam kepemilikan saham perusahaan. Struktur kepemilikan saham mampu mempengaruhi jalannya perusahaan yang pada akhirnya berpengaruh pada kinerja perusahaan dalam mencapai tujuan perusahaan yaitu memaksimalkan nilai perusahaan. Hal ini disebabkan karena adanya kontrol yang dimiliki oleh para pemegang saham. Struktur kepemilikan perusahaan dengan indikator berupa kepemilikan institusional, kepemilikan publik dan kepemilikan manajerial. Kepemilikan institusional merupakan perbandingan antara jumlah saham yang dimiliki institusional dengan total keseluruhan saham. Kepemilikan publik yang merupakan perbandingan antara jumlah saham yang dimiliki publik dengan total keseluruhan saham sedangkan kepemilikan manajerial yang merupakan perbandingan antara jumlah saham yang dimiliki manajerial dengan total keseluruhan saham. (Yunan Surono, 2020).

Selain itu, faktor teknikal juga digunakan dalam penelitian ini dengan menggunakan indikator berupa volume perdagangan, frekuensi perdagangan dan nilai perdagangan. Volume perdagangan saham merupakan jumlah lembar saham yang diperdagangkan pada hari tertentu (Halim, 2000). Saham yang aktif diperdagangkan dengan volume perdagangan yang besar menunjukkan saham tersebut diminati oleh investor. Indikator frekuensi perdagangan merupakan jumlah terjadinya transaksi perdagangan saham perusahaan emiten tersebut. Silviyani (2014), menyatakan jika saham dengan frekuensi perdagangan besar diduga dipengaruhi transaksi saham yang sangat aktif yang disebabkan banyaknya minat investor sehingga dapat diketahui bahwa saham tersebut diminati investor atau tidak. Indiaktor nilai perdagangan yang merupakan seluruh nilai dari kegiatan jual atau beli pada saham perusahaan emiten. (Yunan Surono, 2020).

Variabel intervening berupa total pendapatan, yakni kegiatan penjualan baik barang maupun jasa yang dilakukan oleh perusahaan akan berdampak pada pendapatan yang diperoleh perusahaan yang kemudian akan berdampak pada laba atau rugi perusahaan. Pendapatan merupakan arus masuk atau penyelesaian (atau kombinasi keduanya) dari pengiriman atau produksi barang, memberikan jasa atau melakukan aktivitas lain yang merupakan aktivitas utama yang sedang berlangsung. Variabel intervening ini yang jika diuji apakah variabel total pendapatan ini mampu menjadi perantara dari pengaruh hubungan variabel bebas dengan variabel terikat. Variabel terikat menggunakan profitabilitas yang merupakan kemampuan seberapa tingkat keuntungan yang dapat diperoleh oleh perusahaan, semakin besar tingkat keuntungan semakin baik manajemen dalam mengelola perusahaan. Penelitian ini, menggunakan return on asset (ROA), return on equity (ROE), operating profit margin (OPM), gross profit margin (GPM), dan net profit margin (NPM). Penelitian ini menggunakan objek kelompok saham perkebunan yang ada di Bursa Efek Indonesia periode 2014-2020, atau selama 7 periode. Indonesia sebagai salah satu negara penghasil terbesar produk kelapa sawit dan turunannya di pasar dunia, faktor naik turunnya harga produk kelapa sawit dan turunannnya yang akan mempengaruhi besarnya penjualan dan tingkat keuntungan yang diperoleh bagi investor, serta kinerja masing-masing perusahaan emiten yang mempunyai perbedaan yang cukup signifikan. (Yunan Surono, 2020).

\section{Tinjauan Teoritis \\ Teori Investasi}

Tandelilin, (2010) mengemukakan investasi merupakan komitmen atas sejumlah dana atau sumber daya lainnya yang dilakukan pada saat ini, dengan tujuan memperoleh sejumlah keuntungan dimasa datang. Lubis, (2016) berpendapat investasi adalah mengeluarkan sumberdaya finansial atau sumber daya lainnya untuk memiliki suatu asset, dengan tujuan memperoleh sejumlah keuntungan dimasa datang. 
Yunan Surono dan Muhammad Ade Masyhuri, Pengaruh Makro Ekonomi, Struktur Modal, Struktur Kepemilikan, Faktor Teknikal terhadap Profitabilitas dengan Total Pendapatan Sebagai Variabel Intervening pada Sub Sektor Perkebunan Di Bursa Efek Indonesia Periode 2014-2020

\section{Pasar Modal}

Pasar modal merupakan pertemuan antara pihak yang memiliki kelebihan dana dengan pihak yang membutuhkan dana dengan cara memperjual belikan sekuritas. Pasar modal dapat berfungsi sebagai lembaga perantara (intermediaries), fungsi ini menunjukkan peran penting pasar modal dalam menunjang perekonomian, karena pasar modal dapat menghubungkan pihak yang membutuhkan dana dengan pihak yang mempunyai kelebihan dana (Tandelilin, 2010).

\section{Makro Ekonomi}

Ekonomi makro merupakan bagian dari ilmu ekonomi yang mengkhususkan diri dalam mempelajari mekanisme bekerjanya perekonomian secara keseluruhan. Mankiw (2006), mengemukakan bahwa makroekonomi merupakan sebuah studi tentang perekonomian secara menyeluruh, berusaha menjawab pertanyaan-pertanyaan terkait pertumbuhan pendapatan, kemiskinan, inflasi, kestabilan harga, resesi, depresi, pengangguran dan lainnya. Zvie Bodie (2007), mengemukakan bahwa faktor makro ekonomi yang dapat mempengaruhi kondisi perekonominan negara diantaranya inflasi, nilai tukar dan suku bunga.

1. Inflasi merupakan suatu keadaan dalam perekonomian dimana terjadi kenaikan harga-harga secara umum. Samuelson (2002). Inflasi sebagai bagian dari keadaan perekonomian tentu akan dialami oleh setiap Negara, hanya saja setiap Negara memiliki tingkat inflasi yang berbeda-beda. Untuk mengukur tingkat inflasi dapat menggunakan indek harga konsumen. Di Indonesia informasi mengenai inflasi dikelola oleh suatu badan yaitu Badan Pusat Statistik (BPS).

2. Kurs merupakan harga suatu mata uang terhadap mata uang lainnya. Nilai tukar nominal (nominal exchange rate) merupakan harga relatif dari mata uang dua negara nilai tukar adalah tingkat harga yang disepakati penduduk kedua negara untuk saling melakukan perdagangan. (Mankiw, 2006).

3. Suku bunga (Suku Bunga Bank Indonesia) merupakan tingkat suku bunga yang ditetapkan oleh BI sebagai patokan bagi suku bunga pinjaman maupun simpanan bagi bank dan atau lembagalembaga keuangan di seluruh Indonesia. Tandelilin (2010) mengemukakan bahwa tingkat suku bunga yang meningkat dapat menyebabkan investor menarik investasinya pada saham dan memindahkannya berupa tabungan ataupun deposito.

4. Jumlah uang beredar merupakan semua jenis uang yang ada di dalam perekonomian yaitu jumlah dari mata uang dalam peredaran ditambah dengan uang giral dalam bank-bank umum.

\section{Struktur Modal}

Struktur modal (solvabilitas) merupakan komposisi antara hutang dengan modal sendiri (ekuitas) yang dimiliki oleh perusahaan. (Sudana, 2011), rasio solvabilitas mengukur berapa besar penggunaan utang dalam pembelanjaan perusahaan. Solvabilitas digunakan untuk mengukur kemampuan perusahaan untuk membayar seluruh kewajibannya, baik jangka pendek maupun jangka panjang apabila perusahaan dibubarkan (dilikuidasi). Indikator struktur modal yang digunakan dalam penelitian ini yakni;

1. Debt to Assets Ratio (DAR) merupakan rasio hutang yang digunakan untuk mengukur seberapa besar aktiva perusahaan dibiayai oleh hutang atau seberapa besar hutang perusahaan berpengaruh terhadap pengelolaan aktiva. Adapun rumus yang digunakan adalah :

Debt to Assets Ratio $=\frac{\text { Total Debt }}{\text { Total Assets }}$

2. Debt to Equity Ratio merupakan indikator yang digunakan untuk menilai utang dengan ekuitas. Indikator ini membandingkan antara seluruh utang, termasuk utang lancar dengan seluruh ekuitas, yang bermanfaat untuk mengetahui jumlah dana yang disediakan peminjam (kreditor) dengan pemilik perusahaan, sehingga dapat diketahui setiap rupiah modal sendiri yang dijadikan untuk jaminan utang. Adapun formula yang digunakan adalah:

Debt to Equity Ratio $=\frac{\text { Total Utang }}{\text { Ekuitas }}$

\section{Struktur Kepemilikan}

Sudana (2011), mengemukakan struktur kepemilikan merupakan pemisahan antara pemilik perusahaan dan manajer perusahaan. Pemilik atau pemegang saham merupakan pihak yang menyertakan modal kedalam perusahaan, sedangkan manajer merupakan pihak yang ditunjuk pemilik dan diberi kewenangan mengambil keputusan dalam mengelola perusahaan, dengan harapan manajer bertindak sesuai dengan kepentingan pemilik. Struktur kepemilikan saham mampu mempengaruhi jalannya perusahaan yang pada akhirnya berpengaruh pada kinerja perusahaan dalam mencapai tujuan perusahaan yaitu memaksimalkan nilai perusahaan. Pelaksanaan operasi suatu perusahaan, diwakili oleh direksi (agents) yang ditunjuk oleh para pemegang saham (principals). Dalam penelitian ini terdapat dua struktur kepemilikan yang terdiri dari:

1. Kepemilikan institusional merupakan kepemilikan saham perusahaan yang dimiliki oleh institusi atau lembaga seperti perusahaan asuransi, bank, perusahaan investasi dan kepemilikan institusi lain, semakin tinggi tingkat kepemilikan institusional maka semakin kuat tingkat pengendalian yang dilakukan oleh pihak eksternal terhadap perusahaan sehingga agency conflict yang terjadi di dalam 
perusahaan akan semakin berkurang dan nilai perusahaan akan semakin meningkat. (Jensen dan Meckling, 1976).

2. kepemilikan publik merupakan proporsi atau jumlah kepemilikan saham yang dimiliki oleh publik atau masyarakat umum yang tidak memiliki hubungan istimewa dengan perusahaan.

3. Kepemilikan manajerial merupakan suatu kondisi dimana manajer mengambil bagian dalam struktur modal perusahaan sehingga manajer berperan ganda sebagai manajer sekaligus pemegang saham di perusahaan. Kepemilikan saham oleh pihak manajemen akan menjadikan nilai perusahaan meningkat karena manajemen melaksanakan dan selalu mengawasi perkembangan perusahaan sekaligus memperhitungkan kebijakan yang terbaik, sehingga akan bekerja lebih proaktif dalam mewujudkan kepentingan pemegang saham dan akan meningkatkan kepercayaan, kemudian nilai perusahaan akan naik.

\section{Faktor Teknikal}

Faktor teknikal merupakan suatu studi yang menggambarkan pola-pola pergerakan harga dan volume penjualan suatu sekuritas yang berasal dari data-data historis. Dengan analisis teknikal investor hanya perlu mengidentifikasi bagaimana kecenderungan pergerakan harga saham dan menentukan kapan waktu yang tepat untuk mengambil tindakan menahan, membeli atau menjual saham, dan memanaatkan waktu penyesuaian harga saham sehingga mampu menghasilkan laba. Faktor teknikal dalam penelitian ini yakni volume perdagangan, frekuensi perdagangan, dan nilai perdagangan.

1. Volume perdagangan saham merupakan keseluruhan nilai transaksi pembelian maupun penjualan saham oleh investor, yang berarti sebagai jumlah lembar saham yang diperdagangkan pada hari tertentu. Halim (2000). Perdagangan suatu saham yang aktif dengan volume perdagangan yang besar menunjukkan bahwa saham tersebut diminati oleh investor yang berarti saham tersebut cepat diperdagangkan. Volume perdagangan saham merupakan indikator yang digunakan dalam análisis teknikal pada penilaian harga saham dan suatu instrumen yang dapat digunakan untuk melihat reaksi pasar modal terhadap informasi melalui parameter pergerakan aktivitas volume perdagangan saham di pasar.

2. Frekuensi perdagangan saham adalah berapa kali terjadinya transaksi jual beli pada saham yang bersangkutan pada perdagangan di waktu tertentu, yang merupakan jumlah terjadinya transaksi perdagangan pada saham itu sendiri. Saham yang memiliki frekuensi perdagangan besar diduga dipengaruhi transaksi saham yang sangat aktif, hal ini disebabkan karena banyaknya minat investor, dengan demikian dapat diketahui saham tersebut diminati investor atau tidak. (Silviyani, 2014).

3. Nilai perdagangan adalah kegiatan jual atau beli saham untuk mendapatkan keuntungan dari selisih harga pembelian awal terhadap harga jual terakhir (capital gain). Investor termotivasi untuk memperoleh saham sebanyak mungkin dengan tujuan mendapat pembagian dividen berkala dan atau kekuatan voting pada dewan pemilik saham.

\section{Profitabilitas}

Profitabilitas merupakan rasio untuk mengukur kemampuan perusahaan untuk menghasilkan laba dengan menggunakan sumber-sumber yang dimiliki perusahaan, seperti aktiva, modal, atau penjualan perusahaan, sekaligus memberikan gambaran ukuran tingkat efektivitas manajemen suatu perusahaan. (Sudana, 2011). Profitabilitas dalam penelitian ini menggunakan indikator antaralain;

1. Gross Profit Margin merupakan perbandingan antara laba kotor dengan penjualan, laba kotor merupakan indikator awal mengenai pencapaian laba perusahaan. (Toto Prihadi, 2011). Formula yang digunakan yakni;

\section{Gross Margin= $\frac{\text { Penjualan bersih-Harga pokok penjualan }}{\text { Penjualan bersih }} \times 100$}

2. Operating profit margin merupakan rasio untuk mengukur kemampuan untuk menghasilkan laba sebelum bunga dan pajak dengan penjualan yang dicapai perusahaan. (Sudana, 2011). Formula yang digunakan yakni;

Operating Profit margin $=\frac{\text { Laba operasi }}{\text { Penjualan }} \times 100$

3. Net profit margin adalah rasio untuk mengukur kemampuan perusahaan untuk menghasilkan laba bersih dari penjualan yang dilakukan perusahaan. (Sudana, 2011). Formula yang digunakan yakni;

4. Net Profit Margin $=$ $\frac{\text { Laba Bersih Sesudah Pajak }}{\text { Penjualan }} \times 100 \%$

5. Return on Invertment (ROI) merupakan cara mengukur kemampuan perusahaan dengan keseluruhan dana yang ditanamkan dalam aktiva yang akan digunakan untuk operasinya perusahaan untuk menghasilkan keuntungan. Kasmir (2008). Formula yang digunakan yakni;

6. Return On Investment $=$ $\frac{\text { Laba Bersih Setelah Pajak }}{\text { Total Aktiva }} \times 100 \%$

7. Return On Equity merupakan rasio untuk mengukur laba bersih sesudah pajak dengan modal sendiri. Kasmir (2008). Formula yang digunakan yakni;

8. Return On Equity = $\frac{\text { Laba Bersih Setelah Pajak }}{\text { Modal sendiri }} \times 100 \%$ 
Yunan Surono dan Muhammad Ade Masyhuri, Pengaruh Makro Ekonomi, Struktur Modal, Struktur Kepemilikan, Faktor Teknikal terhadap Profitabilitas dengan Total Pendapatan Sebagai Variabel Intervening pada Sub Sektor Perkebunan Di Bursa Efek Indonesia Periode 2014-2020

\section{Total pendapatan}

Pendapatan (Revenue) merupakan peningkatan dalam aktiva suatu organisasi atau penurunan dalam kewajiban - kewajibannya selama suatu periode akuntansi, terutama yang berasal dari aktiva operasi. Pendapatan dapat juga dikatakan sebagai penghasilan yang timbul dari aktivitas perusahaan yang dikenal dengan sebutan yang berbeda seperti penjualan, penghasilan jasa (fees), bunga, dividen, royalti, dan sewa. Kamus Ekonomi dan Bisnis (Hadi dan Hastuti, 2015).

\section{METODE}

Penelitian ini menggunakanempat variabel bebas yakni variabel makro ekonomi, struktur modal, struktur kepemilikan dan faktor teknikal, dengan variabel profitabilitas sebagai variabel terikat serta total pendapatan sebagai variabel intervening, dimana perhitungan analisis dengan menggunakan Partial Least Square dengan menggunakan software Smart PLS 3.0. Keunggulan metode ini adalah tidak memerlukan asumsi dan dapat diestimasi dengan jumlah sampel yang relatif kecil. (Haryono, 2017). Penelitian ini menguji pengaruh antar variabel, namun hubungan pengaruh antar variabel tersebut dalam penelitian ini masih cenderung lemah atau belum diketahui secara pasti, penelitian ini dapat juga bersifat konfirmasi teori (theorical testing) dan merekomendasikan hubungan yang belum ada dasar teorinya (eksploratori). Data variabel tersebut akan menjadi distribution free (tidak mengasumsikan data berdistribusi tertentu, dapat berupa kategori nominal, ordinal, interval dan rasio). Langkah-langkah pengujian model penelitian berbasis Partial Least Square, (Yamin, 2011) yakni:

1. Membuat rancangan model struktural (inner model), dengan membuat fomulasi model hubungan antar konstruk.

2. Membuat rancangan outer model, dengan membuat spesifikasi hubungan antar konstruk laten dengan konstruknya (reflektif).

3. Membuat konstruksi diagram jalurnya, dengan membuat visualisasi hubungan antar konstruk laten dengan konstruknya.
4. Mengestimasi model dengan menggunakan skema pemilihan weighting dalam proses estimasi model.

5. Melakukan evaluasi model dengan melihat evaluasi terhadap model pengukuran dan evaluasi model structural.

6. Pengujian hipotesis dan interpretasi.

\section{Populasi dan Sampel}

Populasi yang digunakan adalah kelompok saham sub sektor perkebunan dari tahun 2014 - 2020 sebanyak 21 perusahaan emiten. Pengambilan sampel menggunakan metode purposive sampling, yaitu pemilihan sampel berdasarkan pada kesesuaian karakteristik dan kriteria sampel yang ditentukan peneliti agar diperoleh sampel yang representatif (Ferdinand, 2006). Sampel yang digunakan berdasarkan kriteria berikut;

1. Perusahaan yang diteliti adalah perusahaan sub sektor perkebunan yang sudah go public dan terdaftar di BEI dan masih melakukan kegiatan operasinya sampai dengan Desember 2020, terdapat 21 perusahaan emiten.

2. Perusahaan emiten yang memiliki data yang lengkap dari laporan keuangan tahunan selama periode penelitian tahun 2014 - 2020, yang tidak lengkap sebanyak 8 emiten yakni ANJT, CSRA, GOLL, MAGP, MGRO, PGUN, PNGO, dan PSGO.

3. Perusahaan emiten tidak memiliki data ekuitas negatif dari laporan keuangan tahunannya selama periode penelitian tahun 2014 - 2020, terdapat 1 perusahaan yakni dengan kode UNSP.

4. Perusahaan emiten yang menggunakan satuan mata uang rupiah dari laporan keuangannya selama periode penelitian tahun 2014 - 2020, terdapat 1 perusahaan emiten yang menggunakan US\$ yakni ANJT.

Dari kriteria penarikan sampel diatas, diperoleh sampel sebanyak 11 perusahaan emiten yang menjadi objek penelitian.

\section{HASIL DAN PEMBAHASAN}

Hasil penelitian ini, menunjukkan bahwa nilai Construct Reliability and Validity adalah sebagai berikut;

Tabel 1. Nilai Construct Reliability and Validity PLS algorithm ketiga

\begin{tabular}{lrrrr}
\hline & Cronbach's Alpha & rho_A & Composite Reliability & Average variance Extracted \\
\hline Faktor Teknikal & $\mathbf{0 . 8 8 8}$ & $\mathbf{0 . 9 6 3}$ & $\mathbf{0 . 9 2 9}$ & $\mathbf{0 . 8 1 5}$ \\
Makro Ekonomi & $\mathbf{0 . 6 7 8}$ & $\mathbf{0 . 7 1 8}$ & $\mathbf{0 . 8 2 5}$ & $\mathbf{0 . 6 1 5}$ \\
Profitabilitas & $\mathbf{0 . 8 8 1}$ & $\mathbf{0 . 9 3 7}$ & $\mathbf{0 . 9 0 7}$ & $\mathbf{0 . 6 6 7}$ \\
Struktur Kepemilikan & $\mathbf{0 . 5 3 8}$ & $\mathbf{0 . 5 8 8}$ & $\mathbf{0 . 8 0 7}$ & $\mathbf{0 . 6 7 8}$ \\
Struktur Modal & $\mathbf{0 . 8 0 2}$ & $\mathbf{0 . 8 0 3}$ & $\mathbf{0 . 9 1 0}$ & $\mathbf{0 . 8 3 5}$ \\
Total Pendapatan & $\mathbf{1 . 0 0 0}$ & $\mathbf{1 . 0 0 0}$ & $\mathbf{1 . 0 0 0}$ & $\mathbf{1 . 0 0 0}$ \\
\hline Sumber :
\end{tabular}


Yunan Surono dan Muhammad Ade Masyhuri, Pengaruh Makro Ekonomi, Struktur Modal, Struktur Kepemilikan, Faktor Teknikal terhadap Profitabilitas dengan Total Pendapatan Sebagai Variabel Intervening pada Sub Sektor Perkebunan Di Bursa Efek Indonesia Periode 2014-2020

Berdasarkan tabel 1. terlihat nilai Cronbach's Alpha yang mempunyai nilai diatas 0,7 dalam kategori handal sedangkan yang dibawah 0,7 yakni variabel makro ekonomi dengan nilai Cronbach's Alpha sebesar 0,678 dan variabel struktur kepemilikan dengan nilai Cronbach's Alpha sebesar 0,538, hal tersebut menggambarkan bahwa uji reliabilitas belum memenuhi syarat atau masih memiliki masalah pada kelayakan datanya akan tetapi masih dapat diterima atau dalam kategori culup handal (jika pada riset tahap pengembangan skala maka angka 0,5 sampai 0,6 masih dapat diterima) dan nilai Average Variance Extracted mempunyai nilai diatas 0,5 ., yang berarti data tersebut sudah valid. Adapun visualisasi hubungan antar variabel laten dengan konstruknya dan juga hubungan antar variabel laten seperti terlihat pada gambar berikut;

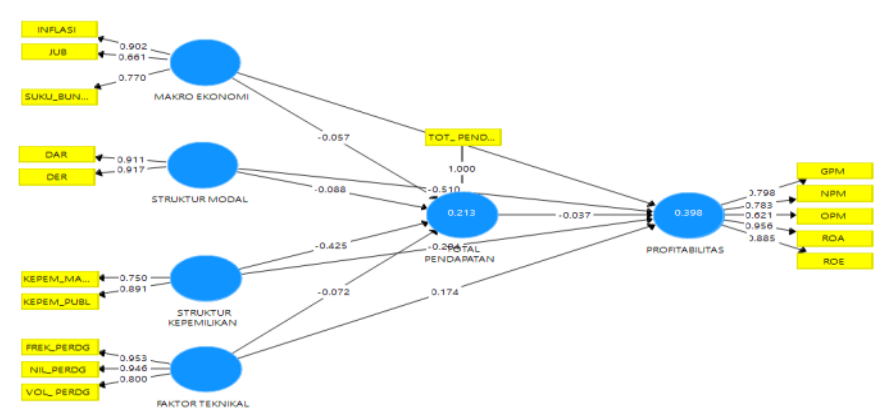

Gambar 1. hasil konstruksi penelitian ketiga.
Berdasarkan panduan yang disampaikan oleh Ghozali (2013), maka pada gambar 2 terlihat bahwa pada variabel makro ekonomi dengan indikator yang memiliki nilai loading factor dibawah 0,7 adalah indikator JUB (Jumlah Uang Beredar) yakni sebesar 0,661 . Indikator variabel profitabilitas yang memiliki nilai loading factor dibawah 0,7 yakni OPM (Operating Profit Margin) yakni sebesar 0,621., dan tidak mengalami perubahan yang signifikan, hal tersebut menggambarkan bahwa uji reliabilitas belum memenuhi syarat atau masih memiliki masalah pada kelayakan datanya akan tetapi masih dapat diterima atau dalam kategori culup handal (jika pada riset tahap pengembangan skala maka angka 0,5 sampai 0,6 masih dapat diterima). Average Variance Extracted (uji validitas), semua variabel telah memenuhi syarat yakni diatas 0,5., hal tersebut menggambarkan bahwa uji validitas telah memenuhi syarat atau telah memiliki kelayakan data. Yamin (2011) mengemukakan dalam penelitian pengembangan model atau indikator baru nilai loading factor antara 0,5-0,6 masih dapat diterima.

Langkah berikutnya adalah melihat besarnya Collinearity Statistic (VIF), yang akan memberikan gambaran tentang apakah data tersebut terjadi multikolinearitas atau tidak. Hasil nilai outer loading VIF (Outer VIF values) dapat terlihat pada tabel 2 berikut:

Tabel 2 Nilai VIF (Variance Inflation Factors)

\begin{tabular}{|c|c|c|c|c|c|c|}
\hline & $\begin{array}{l}\text { Faktor } \\
\text { Teknikal }\end{array}$ & $\begin{array}{l}\text { Makro } \\
\text { Ekonomi }\end{array}$ & Profitabilitas & $\begin{array}{l}\text { Struktur } \\
\text { Kepemilikan }\end{array}$ & $\begin{array}{c}\text { Struktur } \\
\text { Modal }\end{array}$ & Total Pendapatan \\
\hline Faktor Teknikal & & & 1.177 & & & 1.171 \\
\hline Makro Ekonomi & & & 1.057 & & & 1.053 \\
\hline Profitabilitas & & & & & & \\
\hline Struktur Kepemilikan & & & 1.330 & & & 1.101 \\
\hline Struktur Modal & & & 1.111 & & & 1.101 \\
\hline Total Pendapatan & & & 1.271 & & & \\
\hline
\end{tabular}

Sumber : data hasil PLS, 2021.

Tabel 2. nilai inner loading VIF (inner VIF values) menunjukkan tidak terjadi multikolinearitas dimana pada variabel tersebut mempunyai nilai kurang dari 5, warna hijau menunjukkan bahwa variabel tersebut adalah layak. Langkah selanjutnya kita akan melakukan perhitungan (calculate) dengan melakukan
Bootstraping. Hasil perhitungan (calculate) dengan melakukan Bootstraping pada Smart PLS 3.0, diperoleh nilai koeffisien jalur (path coefficients) yang terdiri dari original sample $(\mathrm{O})$, sample mean $\mathrm{s}(\mathrm{M})$, standard deviation (STDEV), $\mathrm{T}$ statistics ([O/STDEV]) dan $\mathrm{P}$ values seperti pada tabel 3 berikut;

Tabel 3 Nilai koeffisien jalur (path coefficients) hasil Bootstraping

\begin{tabular}{|c|c|c|c|c|c|}
\hline & $\begin{array}{l}\text { Original } \\
\text { Sample } \\
(\mathrm{O}) \\
\end{array}$ & $\begin{array}{l}\text { Sample } \\
\text { Mean (M) }\end{array}$ & $\begin{array}{l}\text { Standard } \\
\text { Deviation } \\
(\text { STDEV) } \\
\end{array}$ & $\begin{array}{c}\text { T Statistics } \\
([\mathrm{O} / \mathrm{STDEV}])\end{array}$ & P Values \\
\hline Faktor Teknikal -> Profitabilitas & 0.174 & 0.184 & $\mathbf{0 . 1 2 8}$ & 1.356 & 0.176 \\
\hline Faktor Teknikal -> Total Pendapatan & -0.072 & -0.071 & 0.070 & 1.024 & 0.306 \\
\hline Makro Ekonomi -> Profitabilitas & 0.089 & 0.110 & 0.120 & 0.742 & 0.458 \\
\hline Makro Ekonomi -> Total Pendapatan & -0.057 & -0.063 & 0.122 & 0.464 & 0.643 \\
\hline Struktur Kepemilikan -> Profitabilitas & -0.204 & -0.202 & 0.107 & 1.918 & 0.056 \\
\hline Struktur Kepemilikan -> Total Pendapatan & -0.425 & -0.418 & 0.081 & 5.251 & 0.000 \\
\hline
\end{tabular}


Yunan Surono dan Muhammad Ade Masyhuri, Pengaruh Makro Ekonomi, Struktur Modal, Struktur Kepemilikan, Faktor Teknikal terhadap Profitabilitas dengan Total Pendapatan Sebagai Variabel Intervening pada Sub Sektor Perkebunan Di Bursa Efek Indonesia Periode 2014-2020

\begin{tabular}{|c|c|c|c|c|c|}
\hline Struktur Modal -> Profitabilitas & -0.510 & -0.500 & 0.108 & 4.734 & 0.000 \\
\hline Struktur Modal -> Total Pendapatan & -0.088 & -0.093 & 0.102 & 0.865 & 0.387 \\
\hline Total Pendapatan -> Profitabilitas & -0.037 & $-\mathbf{0 . 0 3 2}$ & 0.098 & 0.375 & 0.708 \\
\hline
\end{tabular}

Sumber : data hasil PLS, 2021.

Hasil perhitungan path coeffisien berdasarkan tabel 3 tersebut menunjukkan bahwa;

1. Variabel faktor teknikal tidak berpengaruh terhadap variabel profitabilitas karena nilai $\mathrm{P}$ values sebesar 0,176 atau lebih besar dari 0,05 maka hubungan antar variabel tersebut dikatakan tidak berpengaruh. Pada gambar 2 juga terlihat

2. Variabel faktor teknikal tidak berpengaruh terhadap variabel total pendapatan karena nilai $\mathrm{P}$ values sebesar 0,306 yakni lebih besar dari 0,05 maka hubungan antar variabel tersebut dikatakan tidak berpengaruh.

3. Variabel makro ekonomi tidak berpengaruh terhadap variabel profitabilitas, karena nilai $\mathrm{P}$ values sebesar 0,458 yakni lebih besar dari 0,05 maka hubungan antar variabel tersebut dikatakan tidak berpengaruh.

4. Variabel makro ekonomi tidak berpengaruh terhadap variabel total pendapatan karena nilai $\mathrm{P}$ values sebesar 0,643 sehingga lebih besar dari 0,05 maka hubungan antar variabel tersebut dikatakan tidak berpengaruh.

5. Variabel struktur kepemilikan tidak berpengaruh terhadap variabel profitabilitas karena nilai $\mathrm{P}$ values sebesar 0,056 sehingga lebih besar dari 0,05 maka hubungan antar variabel tersebut dikatakan tidak berpengaruh.
6. Variabel struktur kepemilikan berpengaruh terhadap variabel total pendapatan karena nilai $P$ values sebesar 0,000 sehingga lebih kecil dari 0,05 maka hubungan antar variabel tersebut dikatakan berpengaruh.

7. Variabel struktur modal berpengaruh terhadap variabel profitabilitas karena nilai $\mathrm{P}$ values sebesar 0,000 sehingga lebih kecil dari 0,05 maka hubungan antar variabel tersebut dikatakan berpengaruh.

8. Variabel struktur modal tidak berpengaruh terhadap variabel total pendapatan karena nilai $\mathrm{P}$ values sebesar 0,387 sehingga lebih besar dari 0,05 maka hubungan antar variabel tersebut dikatakan tidak berpengaruh.

9. Variabel total pendapatan tidak berpengaruh terhadap variabel profitabilitas karena nilai $\mathrm{P}$ values sebesar 0,708 sehingga lebih besar dari 0,05 maka hubungan antar variabel tersebut dikatakan tidak berpengaruh.

Hasil bootstraping juga menghasilkan tabel result for outer loadings. Tabel ini menggambarkan kemampuan merefleksikan dan signifikansi indikator terhadap variabelnya, seperti terlihat pada nilai outer loading pada model ketiga pada tabel 4 berikut;

Tabel 4 Nilai outer loading hasil Bootstraping

\begin{tabular}{|c|c|c|c|c|c|}
\hline & $\begin{array}{l}\text { Original } \\
\text { Sample (O) }\end{array}$ & $\begin{array}{l}\text { Sample } \\
\text { Mean (M) }\end{array}$ & $\begin{array}{c}\text { Standard DeviatiOn } \\
\text { (STDEV) }\end{array}$ & $\begin{array}{l}\text { T Statistics } \\
\text { ([O/STDEV]) }\end{array}$ & P Values \\
\hline DAR <- Struktur Modal & 0.911 & $\mathbf{0 . 9 2 0}$ & 0.018 & 49.502 & 0.000 \\
\hline DER <- Struktur Modal & 0.917 & 0.922 & 0.021 & 43.528 & 0.000 \\
\hline GPM $<$ - Profitabilitas & 0.798 & 0.813 & 0.084 & 9.512 & 0.000 \\
\hline Inflasi <- Makro Ekonomi & 0.902 & 0.842 & 0.172 & 5.242 & 0.000 \\
\hline JUB $<-$ Makro Ekonomi & 0.661 & 0.647 & 0.191 & 3.459 & 0.001 \\
\hline Nil_Perdg <- Faktor Teknikal & 0.946 & 0.911 & 0.186 & 5.084 & 0.000 \\
\hline NPM $<-$ Profitabilitas & 0.783 & 0.849 & 0.073 & 10.665 & 0.000 \\
\hline GPM $<-$ Profitabilitas & 0.621 & 0.719 & 0.091 & 6.852 & 0.000 \\
\hline ROA <- Profitabilitas & 0.956 & 0.949 & $\mathbf{0 . 0 2 0}$ & 48.870 & 0.000 \\
\hline ROE $<-$ Profitabilitas & 0.885 & 0.880 & $\mathbf{0 . 0 2 7}$ & 32.353 & 0.000 \\
\hline
\end{tabular}

Sumber : data hasil PLS, 2021.

Tabel 4 menampilkan nilai outer loading hasil Bootstraping, yang menggambarkan bahwa masingmasing indikator mempunyai pengaruh yang signifikan terhadap variabelnya, hal tersebut menggambarkan bahwa setiap indikator mampu merefleksikan dari variabel yang dibentuknya. Berikut merupakan gambar hasil Bootstraping yang menampilkan nilai outer loading seperti terlihat pada gambar berikut; 
Yunan Surono dan Muhammad Ade Masyhuri, Pengaruh Makro Ekonomi, Struktur Modal, Struktur Kepemilikan, Faktor Teknikal terhadap Profitabilitas dengan Total Pendapatan Sebagai Variabel Intervening pada Sub Sektor Perkebunan Di Bursa

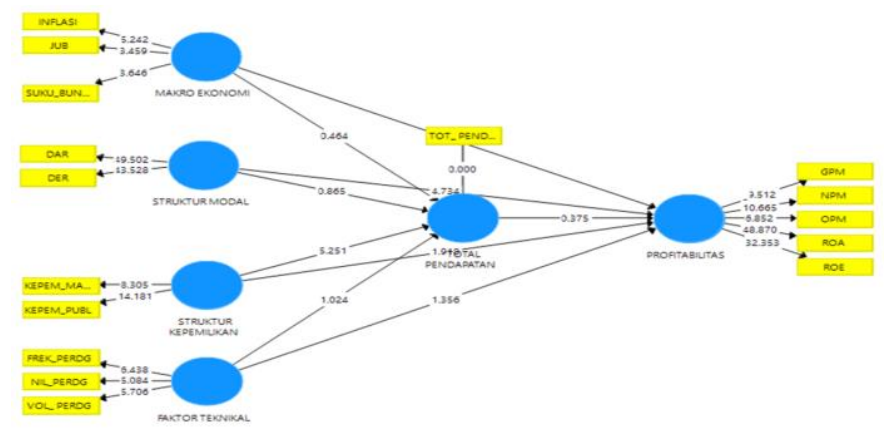

Gambar 2. Hasil Bootstraping konstruksi ketiga.

Hasil bootstraping juga memperlihatkan pengaruh tidak langsung dari variabel bebas yakni variabel makro ekonomi, struktur modal, struktur kepemilikan dan faktor teknikal terhadap profitabilitas dengan total pendapatan sebagai variabel intervening, yang dapat dilihat pada tabel 5 berikut;

Tabel 5. Specific Indirect Effects hasil Bootstraping

\begin{tabular}{|c|c|c|c|c|c|}
\hline & $\begin{array}{l}\text { Original } \\
\text { Sample } \\
(\mathrm{O})\end{array}$ & $\begin{array}{l}\text { Sample } \\
\text { Mean } \\
(\mathrm{M})\end{array}$ & $\begin{array}{l}\text { Standard } \\
\text { Deviation } \\
(\text { STDEV) }\end{array}$ & $\begin{array}{c}\text { T Statistics } \\
([\mathrm{O} / \mathrm{STDEV}])\end{array}$ & P Values \\
\hline Faktor Teknikal -> Total Pendapatan -> Profitabilitas & $\mathbf{0 . 0 0 3}$ & 0.002 & $\mathbf{0 . 0 1 1}$ & 0.237 & 0.813 \\
\hline Struktur Kepemilikan -> Total Pendapatan -> Profitabilitas & 0.016 & $\mathbf{0 . 0 1 2}$ & 0.044 & 0.358 & 0.720 \\
\hline Struktur Modal -> Total Pendapatan -> Profitabilitas & 0.003 & 0.000 & 0.014 & 0.230 & 0.818 \\
\hline
\end{tabular}

Sumber : data hasil PLS, 2021.

Hasil perhitungan path coeffisien untuk melihat pengaruh tidak langsung berdasarkan tabel 5 . tersebut menunjukkan bahwa;

1. Variabel faktor teknikal tidak berpengaruh terhadap variabel profitabilitas dengan total pendapatan sebagai variabel intervening, karena memiliki nilai $\mathrm{P}$ values sebesar 0,813 atau lebih besar dari 0,05 maka hubungan antar variabel tersebut dikatakan tidak berpengaruh.

2. Variabel makro ekonomi tidak berpengaruh terhadap variabel profitabilitas dengan total pendapatan sebagai variabel intervening, karena memiliki nilai $\mathrm{P}$ values sebesar 0,891 atau lebih besar dari 0,05 maka hubungan antar variabel tersebut dikatakan tidak berpengaruh.

3. Variabel struktur kepemilikan tidak berpengaruh terhadap variabel profitabilitas dengan total pendapatan sebagai variabel intervening, karena memiliki nilai $P$ values sebesar 0,720 atau lebih besar dari 0,05 maka hubungan antar variabel tersebut dikatakan tidak berpengaruh.

4. Variabel struktur modal tidak berpengaruh terhadap variabel profitabilitas dengan total pendapatan sebagai variabel intervening, karena memiliki nilai $\mathrm{P}$ values sebesar 0,818 atau lebih besar dari 0,05 maka hubungan antar variabel tersebut dikatakan tidak berpengaruh.

Pengujian terhadap nilai $R$-square sebagai hasil uji goodness of fit model dilihat dari besaran angka nilai $R$-square, yang dapat dilihat di dalam tabel $R$-square dari hasil running calculate konstruksi kelima pada variabel endogen profitabilitas dan diperoleh angka sebesar 0,398 atau sebesar 39,8\%., pada variabel endogen total pendapatan dan diperoleh angka sebesar 0,213 atau sebesar 21,3\%. Angka tersebut memperlihatkan bahwa besarnya pengaruh keragaman data yang dapat dijelaskan oleh model tersebut adalah sebesar 39,8\%., sisanya sebesar 60,2\% dijelaskan oleh variabel lain yang belum terkandung dalam model tersebut dan termasuk error. Hasil tersebut memberikan makna bahwa model penelitian ini merupakan model yang tergolong moderat, menurut Chin (1998) dalam Ghozali (2013) seperti pada kriteria penilian PLS.

Tabel 6. Specific Indirect Effects hasil Bootstraping

\begin{tabular}{lll}
\hline & R Square & R Square Adjusted \\
\hline Profitabilitas & 0.398 & 0.355 \\
Total Pendapatan & 0.213 & 0.169 \\
\hline
\end{tabular}

Sumber : data hasil PLS, 2021

Berdasarkan hasil di atas, maka dapat dijelaskan hasil penelitian ini berdasarkan uji hipotesis antaralain bahwa:

1. Pengaruh makro ekonomi terhadap total pendapatan pada kelompok saham sub sektor perkebunan di Bursa Efek Indonesia periode 2014 - 2020, menunjukkan bahwa variabel makro ekonomi tidak berpengaruh terhadap variabel total pendapatan, dengan nilai $\mathrm{P}$ values sebesar 0,643 atau $64,3 \%$, dimana lebih besar dari 0,05 atau 5\% dan juga dapat dilihat pada nilai $\mathrm{T}$ statisik yakni sebesar 0,464 atau lebih besar dari 46,4. Nilai path coefficients sebesar 0,057 yang berarti jika terjadi kenaikan sebesar 1 satuan pada makro ekonomi maka akan terjadi penurunan sebesar $-0,057$ satuan pada total pendapatan, variabel makro ekonomi dengan indikator inflasi mempunyai loading factor (outer loading) sebesar 0,902 yang berarti inflasi mampu mengkonstruk makro ekonomi, indikator jumlah uang beredar (JUB) mempunyai loading factor (outer loading) sebesar 0,661 yang berarti inflasi mampu 
Yunan Surono dan Muhammad Ade Masyhuri, Pengaruh Makro Ekonomi, Struktur Modal, Struktur Kepemilikan, Faktor Teknikal terhadap Profitabilitas dengan Total Pendapatan Sebagai Variabel Intervening pada Sub Sektor Perkebunan Di Bursa Efek Indonesia Periode 2014-2020

mengkonstruk makro ekonomi dan indikator suku bunga mempunyai loading factor (outer loading) sebesar 0,770 yang berarti inflasi mampu mengkonstruk makro ekonomi, sedangkan indikator kurs US \$ terhadap rupiah tidak mampu mengkonstruk variabel makro ekonomi sehingga di keluarkan dari konstruksi penelitian.

2. Pengaruh struktur modal terhadap total pendapatan pada kelompok saham sub sektor perkebunan di Bursa Efek Indonesia periode 2014 - 2020, menunjukkan bahwa variabel struktur modal tidak berpengaruh terhadap variabel total pendapatan, dengan nilai $\mathrm{P}$ values sebesar 0,387 atau $38,7 \%$, dimana lebih besar dari 0,05 atau $5 \%$ dan juga dapat dilihat pada nilai $\mathrm{T}$ statisik yakni sebesar 0,865 atau lebih kecil dari 1,96. Nilai path coefficients sebesar 0,088 yang berarti jika terjadi kenaikan sebesar 1 satuan pada struktur modal maka akan terjadi penurunan sebesar $-0,088$ satuan pada total pendapatan, variabel struktur modal dengan indikator debt to asset ratio (DAR) mempunyai loading factor (outer loading) sebesar 0,911 yang berarti DAR mampu mengkonstruk struktur modal, indikator debt to equity ratio (DER) mempunyai loading factor (outer loading) sebesar 0,917 yang berarti DER mampu mengkonstruk struktur modal.

3. Pengaruh struktur kepemilikan terhadap total pendapatan pada kelompok saham sub sektor perkebunan di Bursa Efek Indonesia periode 2014 2020, menunjukkan bahwa variabel struktur kepemilikan berpengaruh terhadap variabel total pendapatan, dengan nilai $P$ values sebesar 0,000 atau $0,0 \%$., dimana lebih kecil dari 0,05 atau $5 \%$ dan juga dapat dilihat pada nilai T statisik yakni sebesar 5,251 atau lebih besar dari 1,96. Nilai path coefficients sebesar $-0,425$ yang berarti jika terjadi kenaikan sebesar 1 satuan pada struktur kepemilikan maka akan terjadi penurunan sebesar $-0,425$ satuan pada total pendapatan, variabel struktur kepemilikan dengan indikator kepemilikan manajerial mempunyai loading factor (outer loading) sebesar 0,750 yang berarti kepemilikan manajerial mampu mengkonstruk struktur kepemilikan, indikator kepemilikan publik mempunyai loading factor (outer loading) sebesar 0,891 yang berarti kepemilikan publik mampu mengkonstruk struktur kepemilikan sedangkan indikator kepemilikan institusional tidak mampu mengkonstruk variabel struktur kepemilikan sehingga di keluarkan dari konstruksi penelitian.

4. Pengaruh faktor teknikal terhadap total pendapatan pada kelompok saham sub sektor perkebunan di Bursa Efek Indonesia periode 2014 - 2020, menunjukkan bahwa variabel faktor teknikal tidak berpengaruh terhadap variabel total pendapatan, dengan nilai $P$ values sebesar 0,306 atau $30,6 \%$, dimana lebih besar dari 0,05 atau $5 \%$ dan juga dapat dilihat pada nilai $\mathrm{T}$ statisik yakni sebesar 1,024 atau lebih kecil dari 1,96. Nilai path coefficients sebesar 0,072 yang berarti jika terjadi kenaikan sebesar 1 satuan pada faktor teknikal maka akan terjadi penurunan sebesar $-0,072$ satuan pada total pendapatan, variabel faktor teknikal dengan indikator frekuensi perdagangan mempunyai loading factor (outer loading) sebesar 0,953 yang berarti frekuensi perdagangan mampu mengkonstruk faktor teknikal, indikator nilai perdagangan mempunyai loading factor (outer loading) sebesar 0,946 yang berarti nilai perdagangan mampu mengkonstruk faktor teknikal dan indikator volume perdagangan mempunyai loading factor (outer loading) sebesar 0,800 juga mampu mengkonstruk variabel faktor teknikal pada konstruksi penelitian.

5. Pengaruh makro ekonomi terhadap profitabilitas pada kelompok saham sub sektor perkebunan di Bursa Efek Indonesia periode 2014 - 2020, menunjukkan bahwa variabel makro ekonomi tidak berpengaruh terhadap variabel profitabilitas dengan nilai $\mathrm{P}$ values sebesar 0,458 atau $45,8 \%$., dimana lebih besar dari 0,05 atau $5 \%$ dan juga dapat dilihat pada nilai $\mathrm{T}$ statisik yakni sebesar 0,742 atau lebih kecil dari 1,96. Nilai path coefficients sebesar 0,089 yang berarti jika terjadi kenaikan sebesar 1 satuan pada makro ekonomi maka akan terjadi kenaikan pula sebesar 0,089 satuan pada profitabilitas, variabel makro ekonomi dengan indikator inflasi mempunyai loading factor (outer loading) sebesar 0,902 yang berarti inflasi mampu mengkonstruk makro ekonomi, indikator jumlah uang beredar (JUB) mempunyai loading factor (outer loading) sebesar 0,661 yang berarti inflasi mampu mengkonstruk makro ekonomi dan indikator suku bunga mempunyai loading factor (outer loading) sebesar 0,770 yang berarti inflasi mampu mengkonstruk makro ekonomi, sedangkan indikator kurs US \$ terhadap rupiah tidak mampu mengkonstruk variabel makro ekonomi sehingga di keluarkan dari konstruksi penelitian. Variabel profitabilitas dengan indikator gross profit margin (GPM) mempunyai loading factor (outer loading) sebesar 0,798 yang berarti GPM mampu mengkonstruk variabel profitabilitas. Indikator net profit margin (NPM) mempunyai loading factor (outer loading) sebesar 0,783 yang berarti NPM mampu mengkonstruk variabel profitabilitas. Indikator operating profit margin (OPM) mempunyai loading factor (outer loading) sebesar 0,621 yang berarti OPM mampu mengkonstruk variabel profitabilitas. Indikator Return On Asset (ROA) mempunyai loading factor (outer loading) sebesar 0,956 yang berarti ROA mampu mengkonstruk variabel profitabilitas dan indikator Return On Equity (ROE) mempunyai loading factor (outer loading) 
sebesar 0,885 yang berarti ROE mampu mengkonstruk variabel profitabilitas.

6. Pengaruh struktur modal terhadap profitabilitas menunjukkan bahwa nilai $P$ values sebesar 0,000 atau 0,0\%., dimana lebih kecil dari 0,05 atau $5 \%$ dan juga dapat dilihat pada nilai $\mathrm{T}$ statisik yakni sebesar 4,734 atau lebih kecil dari 1,96., dengan nilai original sample (OS) sebesar -0,510 yang berarti jika variabel struktur modal mengalami kenaikan 1 satuan maka akan berdampak pada profitabilitas yang akan mengalami penurunan sebesar $-0,510$ satuan.

7. Pengaruh struktur kepemilikan terhadap profitabilitas menunjukkan bahwa nilai $P$ values sebesar 0,056 atau $5,6 \%$., dimana lebih besar dari 0,05 atau $5 \%$ dan juga dapat dilihat pada nilai T statisik yakni sebesar 1,918 atau lebih kecil dari 1,96., dengan nilai original sample (OS) sebesar -0,204 yang berarti jika variabel struktur kepemilikan mengalami kenaikan 1 satuan maka akan berdampak pada profitabilitas yang akan mengalami penurunan sebesar -0,204 satuan.

8. Pengaruh faktor teknikal terhadap profitabilitas pada kelompok saham sub sektor perkebunan di Bursa Efek Indonesia periode 2014 - 2020, menunjukkan bahwa variabel faktor teknikal tidak berpengaruh terhadap variabel profitabilitas dengan nilai $\mathrm{P}$ values sebesar 0,176 atau $17,6 \%$., dimana lebih kecil dari 0,05 atau $5 \%$ dan juga dapat dilihat pada nilai $\mathrm{T}$ statisik yakni sebesar 1,356 atau lebih kecil dari 1,96. Nilai path coefficients sebesar 0,174 yang berarti jika terjadi kenaikan sebesar 1 satuan pada faktor teknikal maka akan terjadi kenaikan pula sebesar 0,174 satuan pada profitabilitas.

9. Pengaruh makro ekonomi terhadap profitabilitas melalui total pendapatan, menunjukkan bahwa nilai $\mathrm{P}$ values sebesar 0,891 atau $89,1 \%$., dimana lebih besar dari 0,05 atau $5 \%$ dan juga dapat dilihat pada nilai $\mathrm{T}$ statisik yakni sebesar 0,138 atau lebih kecil dari 1,96., dengan nilai original sample (OS) sebesar 0,002 yang berarti jika variabel makro ekonomi mengalami kenaikan 1 satuan maka akan berdampak pada profitabilitas yang akan mengalami penurunan sebesar 0,002 satuan melalui total pendapatan. (tabel 5).

10.Pengaruh struktur modal terhadap profitabilitas melalui total pendapatan, menunjukkan bahwa nilai $\mathrm{P}$ values sebesar 0,818 atau $81,8 \%$., dimana lebih besar dari 0,05 atau $5 \%$ dan juga dapat dilihat pada nilai $\mathrm{T}$ statisik yakni sebesar 0,230 atau lebih kecil dari 1,96., dengan nilai original sample (OS) sebesar 0,003 yang berarti jika variabel struktur modal mengalami kenaikan 1 satuan maka akan berdampak pada profitabilitas yang akan mengalami penurunan sebesar 0,003 satuan melalui total pendapatan. (tabel 5).

11.Pengaruh struktur kepemilikan terhadap profitabilitas melalui total pendapatan, menunjukkan bahwa nilai $\mathrm{P}$ values sebesar 0,720 atau 72,0\%., dimana lebih besar dari 0,05 atau 5\% dan juga dapat dilihat pada nilai $\mathrm{T}$ statisik yakni sebesar 0,358 atau lebih kecil dari 1,96., dengan nilai original sample (OS) sebesar 0,016 yang berarti jika variabel struktur modal mengalami kenaikan 1 satuan maka akan berdampak pada profitabilitas yang akan mengalami penurunan sebesar 0,016 satuan melalui total pendapatan. (tabel 5).

12.Pengaruh faktor teknikal terhadap profitabilitas melalui total pendapatan, menunjukkan bahwa nilai $\mathrm{P}$ values sebesar 0,813 atau 81,3\%., dimana lebih besar dari 0,05 atau $5 \%$ dan juga dapat dilihat pada nilai $\mathrm{T}$ statisik yakni sebesar 0,237 atau lebih kecil dari 1,96., dengan nilai original sample (OS) sebesar 0,003 yang berarti jika variabel faktor teknkal mengalami kenaikan 1 satuan maka akan berdampak pada profitabilitas yang akan mengalami penurunan sebesar 0,003 satuan melalui total pendapatan. (tabel $5)$.

\section{SIMPULAN} berikut;

Penelitian ini dapat ditarik kesimpulan sebagai

1. Variabel makro ekonomi tidak berpengaruh terhadap total pendapatan pada kelompok saham sub sektor perkebunan di Bursa Efek Indonesia periode 2014 2020.

2. Variabel struktur modal tidak berpengaruh terhadap total pendapatan pada kelompok saham sub sektor perkebunan di Bursa Efek Indonesia periode 2014 2020.

3. Variabel struktur kepemilikan berpengaruh terhadap total pendapatan pada kelompok saham sub sektor perkebunan di Bursa Efek Indonesia periode 2014 2020.

4. Variabel faktor teknikal tidak berpengaruh terhadap total pendapatan pada kelompok saham sub sektor perkebunan di Bursa Efek Indonesia periode 2014 2020.

5. Variabel makro ekonomi berpengaruh terhadap profitabilitas pada kelompok saham sub sektor perkebunan di Bursa Efek Indonesia periode 2014 2020.

6. Variabel struktur modal tidak berpengaruh terhadap profitabilitas pada kelompok saham sub sektor perkebunan di Bursa Efek Indonesia periode 2014 2020.

7. Variabel struktur kepemilikan tidak berpengaruh terhadap profitabilitas pada kelompok saham sub sektor perkebunan di Bursa Efek Indonesia periode $2014-2020$.

8. Variabel faktor teknikal berpengaruh terhadap profitabilitas pada kelompok saham sub sektor perkebunan di Bursa Efek Indonesia periode 2014 2020. 
9. Makro ekonomi tidak berpengaruh terhadap profitabilitas melalui total pendapatan pada kelompok saham sub sektor perkebunan di Bursa Efek Indonesia periode $2014-2020$.

10. Struktur modal tidak berpengaruh terhadap profitabilitas melalui total pendapatan pada kelompok saham sub sektor perkebunan di Bursa Efek Indonesia periode $2014-2020$.

11.Struktur kepemilikan tidak berpengaruh terhadap profitabilitas melalui total pendapatan pada kelompok saham sub sektor perkebunan di Bursa Efek Indonesia periode $2014-2020$.

12.Faktor teknikal tidak berpengaruh terhadap profitabilitas melalui total pendapatan pada kelompok saham sub sektor perkebunan di Bursa Efek Indonesia periode $2014-2020$.

\section{DAFTAR PUSTAKA}

Bodie, Z., A. Kane, dan A. J. Marcus. 2007. Investment, (7th Ed). New York: McGrow-Hill.

Ferdinand, Augusty, 2006. Metode Penelitian Manajemen: Pedoman Penelitian untuk skripsi, Tesis dan Disertai Ilmu Manajemen. Semarang: Universitas Diponegoro.

Ghozali, Imam. 2013. Aplikasi Analisis Multivariate dengan Program IBM SPSS 21 Update PLS Regresi. Semarang: Badan Penerbit Universitas Diponegoro.

Halim, Hidayat, 2000, Studi Empiris Tentang Pengaruh Volume Perdagangan Dan Return Terhadap BidAsk Spread Saham Industri Rokok di BEJ Dengan Model Korelasi Kesalahan, Jurnal Riset Akuntansi Indonesia, Vol 3, hal 69-85.

Hadi Waluyo dan Dini Hastuti. 2015. Kamus Terbaru Ekonomi Dan Bisnis. Surabaya: Reality Publisher

Haryono, Siswoyo 2017, Metode SEM Untuk Penelitian Manajemen, AMOS LISREL PLS, Luxima Metro Media, Jakarta.

Jensen, M., C., dan W. Meckling, 1976. "Theory of the firm: Managerial behavior, agency cost and ownership structure", Journal of Finance Economic 3:305- 360, di-download dari http://www.nhh.no/for/courses/spring/eco420/jens enmeckling-76.pdf

Kasmir, Jakfar. 2008, Analisis Laporan Keuangan, PT Rajagrafindo Persada, Jakarta.

Kasmir, 2014, Analisis Laporan Keuangan, Edisi Satu. Cetakan ketujuh. Jakarta: PT Raja Grafindo Perkasa.

Mankiw N,Gregory. 2006. Makro Ekonomi, Terjemahan: Fitria Liza, Imam Nurmawan, Jakarta: Penerbit Erlangga.

Samuelson. Paul A. \& William D Nordhaus. 2002. Mikro Ekonomi. Jakarta : Erlangga.

Silviyani. 2014. Pengaruh Likuiditas Perdagangan Saham dan Kapitalisasi Pasar Terhadap Return
Saham Perusahaan Yang Berada Pada Indeks LQ45 Di Bursa Efek Indonesia Periode Tahun 2009-2013 (Studi Empiris PadaPerusahaan Lq45 Di Bursa Efek Indonesia). e-Journal S1 Ak Universitas Pendidikan Ganesha Jurusan Akuntansi SI.(Volume: 2 No. 1.)

Sudana, I Made. 2011. Manajemen Keuangan Perusahaan Teori dan Praktik, ERLANGGA, Surabaya.

Tandelilin, Eduardus. 2010. Portofolio dan Investasi Teori dan Aplikasi. Edisi pertama. Yogyakarta : Kanisius

Toto, Prihadi. 2011. Analisis Laporan Keuangan Teori dan Aplikasi. Jakarta: Penerbit PPM.

Yamin, Sofyan. 2011, Generasi Baru Mengolah Data Penelitian Dengan Partial Least Square Path Modelling. Jakarta, Salemba Infotek.

Yunan Surono, Amilia Paramita \& Ali Akbar. 2020 Pengaruh Struktur Modal, Struktur Kepemilikan, Faktor Teknikal Terhadap Profitabilitas dengan Total Pendapatan Sebagai Variabel Moderasi Pada Sub Sektor Perkebunan Di Bursa Efek Indonesia Periode 2015-2018. Jurnal Manajemen dan Sains, 5(2), Oktober 2020, 218-226. 